VISNYK LVIV UNIV.

ерія геогр. 2012. иn. 40. . 1. . 201-213 Ser. Geogr. 2012. N 40. . 1. P. 201-213

$911.3: 572(477)$

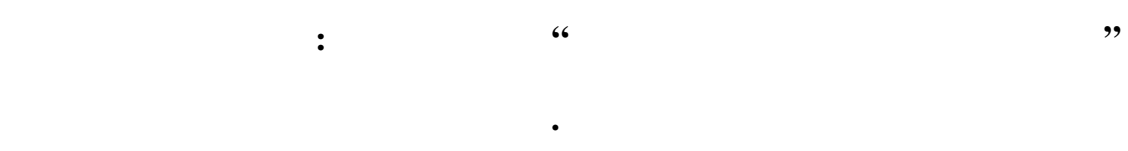

іровогр дський держ вний пед гогічний університет імені олодимир инниченк , вул. евченк, 1, м. іровогр д, 25006, кр їн , e-mail: mails@kspu.kr.ua,andriy_o_domaranskiy@rambler.ru.

\begin{abstract}
озглянуто проблему ідентифік ції н селенням центр льної ч стини кр їни регіону свого прожив ння (н прикл ді мешк нців іровогр дської обл.). ро н лізов но результ ти соціологічного опитув ння групи експертів як своєрідного індик тор суспільної думки т водноч с чин-

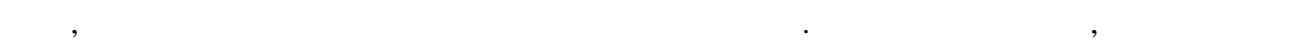
"експертне середовище" не може відігр в ти ролі гент вирішення в жливих регіон льних проблем (формув ння концепції кр єзн вчої освіти, перейменув ння дміністр тивних одиниць т ін.).

лючові слов : суспільн ідентифік ція, соціологічне опитув ння, “експертне середовище", регіон, ентр льн кр їн, іровогр дськ обл.
\end{abstract}

ьогодні є неоднозн чність у пит нні ідентифік ції тієї ч стини укр їнських земель, що розміщен у центр льній ч стині держ ви між оділлям, ередньою ддніпрянщиною, онщиною, івнічним ричорномор'ям і врією ( дміністр тивно - у меж х перев жно іровогр дської обл.). зн чення цих теренів у побуті, різних г лузях н уки, з соб х м сової інформ ції, з конод вчих кт $\mathrm{x}$, освітніх методичних м тері л $\mathrm{x}$ т інших сфер х буття суспільств суттєво відрізняються, дезорієнтуючи користув чів т кого роду інформ цією і провокуючи непорозуміння. К непевність, будучи неб ж ним явищем в інформ ційному полі н побутовому рівні, є недопустимою н рівні функціонув ння держ вних інституцій, н уки чи, особливо, освіти. юди, що не м ють точних і вичерпних відомостей про озн чення кр ю свого мешк ння, у процесі н буття зн нь (у якому б віці це не відбув лось) плут ються в інформ ційних орієнтир х, формуючи свої світоглядні принципи н $б$ зі первинно спотворених позицій, і поволі втр ч ють зв' язок з етнічними, історичними, культурними, мовними, господ рськими т іншими особливостями свого регіону, отже, с мопов гу, с мобутність i, врешті, п тріотизм. ре ліях інформ ційного тиску ( поч сти, й “інформ ційних воєн”) з боку різнорідних держ вних, гром дських чи інших суб'єктів це ст є особливо небезпечним.

ля того, щоб д ти вичерпну відповідь н пит ння: к пр вильно озн чув ти центр льноукр їнські терени?, необхідне н йгрунтовніше опр цюв ння кол проблем, н йв жливішими серед яких $є$ т кі: з'ясув ння тр диційних н родних, дміністр тивних, н укових т інших н зв земель центр льної ч стини кр їни; особливості суч сної ідентифік ції регіону прожив ння мешк нцями цих кр їв т суміжних з ними місцевостей; декв тність н зв дміністр тивних одиниць т оптим льність с мого дміністр тивно-територі льного поділу н досліджув них терен х держ ви; визн чення ін-

(C) ом р нський ., 2012 
ституцій, н які можн б покл сти відповід льність 3 н пр цюв ння рекоменд цій, поклик них усунути недоречності.

г лом н йрізном нітнішим вияв м суспільної ідентифік ції (зокрем , і н селення кр їни) присвячен чим л кількість суч сних н укових досліджень у г лузях філософії, психології, соціології, політології, геополітики, історії тощо, де пок зовими ст ли н пр цюв ння . екешкіної, . ергер , . орони, . н тенк , . олов хи, . кєєв , . кс митної, . т ровойтової, . ульги, . дов т ін. $[1,4,5,7,8,10$ т ін.]. ерідко до розгляду подібної проблем тики долуч ються й геогр фи ( ж. олд, оулд, . родзинський, . родзинськ , . елінскі, . сі т ін.) [1]. ериторія центр льної ч стини кр їни (особливо, у меж х іровогр дської обл.) висвітлен , в т кого роду пр цях лише опосередков но.

ослідження пит нь суспільної ідентифік ції потребує з лучення широкого спектр методів н укових досліджень від з г льних до конкретно-н укових (у т кому контексті геогр фічних т історико-геогр фічних). собливо корисним підгрунтям для пошуку відповідей н окреслене коло пит нь можуть ст ти відомості, отрим ні вн слідок з стосув ння методологічного рсен лу соціологічної н уки, зокрем, проведення спецільних тем тичних соціологічних опитув нь.

ідт к, м ючи н меті дослідити особливості ідентифік ції суспільством земель центр льної ч стини кр їни, , головно, для виявлення суч сних тенденцій цього явищ, ми орг нізув ли опитув ння у формі тем тичного нкетув ння. оловними з вд ннями, які д є змогу вирішити т кого роду поступ, є: з’ясув ння того, які існують в рі нти озн чення досліджув ного регіону мешк нцями цих чи суміжних кр їв; чи існує у свідомості суч сних мешк нців кр ю зв'язок з його історичними н зв ми; як змінюється (і чи змінюється) ідентифік ція людьми регіону свого прожив ння з лежно від місця розт шув ння їхнього н селеного пункту, ст ті, віку, н ціон льності, освіти чи сфери з йнятості респондент тощо. ншим пл стом корисної інформ ції, що виявляється в процесі соціологічного опитув ння, є думк т к зв ного експертного середовищ - спеці льно відібр ної групи респондентів, погляд яких н досліджув ну проблем тику може бути особливо цік вим з позицій не стільки фіксув ння особливостей їі суч сного ст ну, скільки з огляду н перспективи її вирішення. дже "експертне середовище", це люди, що з огляду н свій професійний чи дміністр тивний ст тус м ють суттєвий вплив н формув ння і зміну гром дської думки, прийняття різнорідних юридичних рішень тощо. ож, з'ясув ння особливостей персон льної ідентифік ції експерт ми регіону свого мешк ння (i, особливо, діяльності т впливу), рівня їхньої обізн ності в історичних ре ліях, гром дянської зрілості т інших рис, м є принципове зн чення для перспектив вирішення досліджув них проблем. л сне н лізу особливостей суч сної ідентифік ції центр льноукр їнського регіону “експертним середовищем” і присвячен н ш пр ця.

етодик збир ння вихідної інформ ції. ля отрим ння необхідних відомостей про суч сні погляди суспільств (т тієї його ч стини, яку можн вв ж ти його експертною скл довою) н регіон свого прожив ння обр но н уковий метод соціологічного опитув ння, зокрем, тем тичне нкетув ння. е ліз ція т ких пл нів потребув л викон ння робіт, розділених н дв послідовні ет пи: нкетув ння “експертного середовищ " т з г льне нкетув ння н селення центр льної ч стини кр їни. сновними л нк ми ре ліз ції першої ч стини дослідження ст ло: укл д ння переліку необхідних для з'ясув ння пит нь; розт шув ння з пит нь у послідовності, н йоптим льнішій для виявлення поглядів респондентів; розробк структури т ркуш нкети; проб ція ме- 
тодики нкетув ння н респондент х, що перебув ють поз меж ми з г льної вибірки; коректув ння змісту і форми нкети; формув ння списку осіб, що м ють скл сти “експертне середовище"; нкетув ння експертної групи; опр цюв ння й н ліз результ тів нкетув ння групи експертів; формулюв ння висновків. езульт ти т ких дій викл дені нижче. ля викон ння другого (поки нере лізов ного) ет пу робіт необхідне: збир ння ст тистичної інформ ції про скл д і просторовий розподіл н селення центр льної ч стини кр їни; укл д ння ст тистичної вибірки для з г льного нкетув ння н селення; проведення "широкого" соціологічного опитув ння н селення, опр цюв ння й н ліз його результ тів (зокрем , порівняння з погляд ми “експертного середовищ ”); формулюв ння висновків тощо. скільки просторово досліджув ний регіон ф ктично збіг ється 3 дміністр тивними меж ми іровогр дської обл., то всі перелічені соціологічні вимірюв ння проводили з уч стю її мешк нців.

о нкети з умовною н звою “ успільн ідентифік ція центр льноукр їнського регіону” було включено перелік із 17 основних т 6 дод ткових з пит нь. сновні спрямов ні н збир ння інформ ції щодо предмет досліджень, дод ткові - н виявлення окремих індивіду льних х р ктеристик респондентів (вік, ст ть, н ціон льність, місце прожив ння тощо). отири пит ння нкети передб ч ли безпосереднє з пит ння особи, що проводить нкетув ння, i, відповідно, пряму відповідь н неї; інші - с мостійний вибір доцільного в рі нт із з пропонов ного переліку чи формулюв ння нового. ке комбінув ння форм з д ння з пит нь було спрямов не н досягнення ефекту “чистоти відповіді”, щоб уникнути неб ж ної спрямов ності мислення респондентів у р мк х н ведених переліків відповідей і з діяти в нкетув нні істинні відчуття й погляди опитув них.

р ктеристик респондентів “експертного середовищ”, кл д ючи перелік групи експертів, ми пр гнули з лучити до їхнього числ ф хівців тих сфер суспільного буття, що з родом діяльності $є$ н йбільш дотичними до пит нь окресленої дослідженням проблем тики бо ж м ють в гомі в желі впливу в р зі ухв лення в жливих у т кому контексті рішень. жливим критерієм підбору респондентів бул н явність у них н укових чи публіцистичних пр ць, присвячених досліджув ній тем тиці чи окресленому регіону з г лом. о скл ду “експертного середовищ ” увійшли ф хівці-кр єзн вці, яких умовно можн розділити н діячів освіти і н уки (19 осіб), держ вної служби (3), культури й мистецтв (3), підприємницької діяльності (1 особ ) т інших сфер суспільного буття (рис. 1). ф хом серед експертів предст влені: історики (8 осіб), філологи (7), геогр фи (5), економісти (3), біологи (2) т художник (1 особ ) (див. рис. 1)

г лом кількість експертної групи - 26 осіб. них $81 \%$ (21 респондент) м ють н укові ступені, $19 \%$ (5 осіб) не м ють т ких ступенів; 15 респондентів є к ндид т ми н ук (58 \%), 6 - доктор ми н ук (23\%) (див. рис. 1). еред експертів є предст вники різних вікових груп: 18-35 років (4 особи; $15 \%), 36-60$ років (16 осіб; $62 \%)$, ст рше 60 років (6 осіб; $23 \%$ ). ст ттю (див. рис. 1) в експертній групі перев ж ють чоловіки (19 осіб; $73 \%$, менше предст влені жінки (7 осіб; $27 \%$ ). сі респонденти експертного середовищ 3 місцем мешк ння і діяльності предст вляли м. іровогр д, 3 етнічною н лежністю визн чили себе укр їнцями.

н ліз відповідей респондентів “експертного середовищ" д є змогу вирізнити низку дост тньо в жливих особливостей у їхньому ст вленні до окресленої проблем тики, що р зом були сформульов ні у вигляді кількох тез.

- ерев жкн більшість експертів ідентифікує досліджсув ний регіон як центр льноукр їнський, озн чуючи його н зв ми “ентр льн кр їн”, “ентр льноукр їнський регіон” чи, менш вир зно, “ ентр льний регіон” (див. рис. 2). 

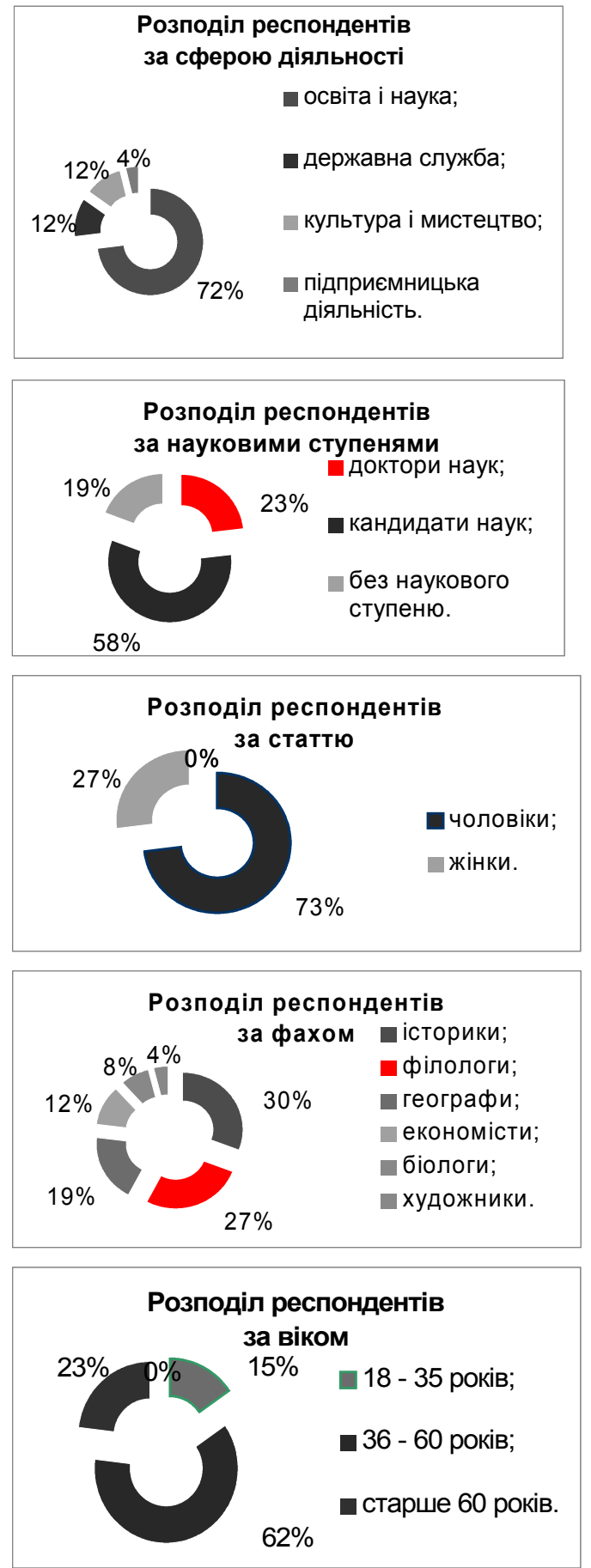

ис. 1. р ктеристики респондентів "експертного середовищ ”. 
к позиція виявляється у відповідях 16 респондентів, що ст новить близько $61 \%$ від з г льної кількості опит них експертів. скільки точними є ці д ні? жливо, що т кого роду відомості отрим ні з відповідей ф хівців н відкрите з пит ння (без пропонов них в рі нтів), отже, їх можн розгляд ти як вияв ре льного “відчуття місця". од тковим ргументом н користь істинності отрим них відомостей про просторову ідентифік цію респондентів є те, що у відповідному пит нні нкети ми свідомо уникли уточнення про підхід до визн чення регіону, не кцентуючи ув ги н тому, чи це м $є$ бути етнічний, історико-культурний, економічний чи якийсь інший критерій. рім того, відкрите пит ння “ к н зив ється регіон, у якому розміщений ш н селений пункт?”, було першим у переліку, пропонов ному експерт м для н д ння відповідей, відт к, є підст ви вв ж ти отрим ні відомості вільними від упередженості, що могл виникнути в р зі глибшого проникнення респондент у зміст нкети. коюсь мірою домін нт з-поміж експертів озн чення “ ентр льн кр їн ”підтверджен і тим, що у відповіді нкетов них н ідентичне пит ння, одн к з переліком можливих в рі нтів відповідей позиції т кого в рі нт є чільними (38 \%, бо 10 зг док), поступ ючись (рис. 2) лише озн ченню “ іровогр дщин ” (42\%, бо 11 зг док). ідповідь н пит ння « ому с ме т кою є ідентифік ція досліджув ного регіону член ми “експертного середовищ ”? певною мірою д є н ліз їхніх відповідей н інші з пит ння нкети т виявлені (і 3 зн чені нижче) у них з кономірності.

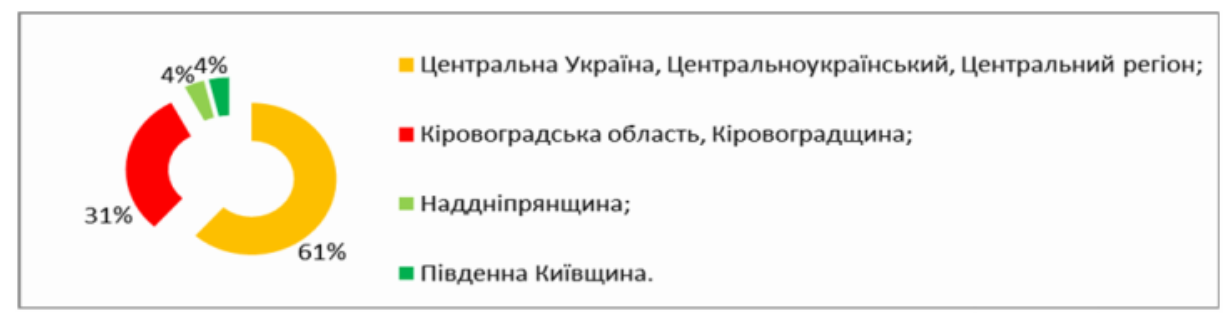

ис. 2. озподіл респондентів 3 відповіддю н відкрите пит ння “ к н зив ється регіон, у якому розміщений ш н селений пункт?”.

- оловними сутнісними орієнтир ми в р зі ідентифік иії експерт ми досліджув ного регіону є $m$ кі критерії, як просторове положення иього кр юн тлі кр їни $m$ його дміністр тивно-територі льн прив'язк, тоді як історичні н родні чи офіційні озн чення кр юм ють порівняно м лий вплив н визн чення позицій ф хівців. ро це свідч ть відповіді експертів н з пит ння обох видів щодо н зви регіону розміщення н селеного пункту їхнього прожив ння - відкрите й в рі тивне. відповіді н відкрите пит ння з положенням кр ю в центр льній ч стині кр їни його н зву пов'язують близько $61 \%$ респондентів (16 осіб); суч сний дміністр тивно-територі льний поділ є основним ідентифік ційним пок зником для $31 \%$ опит них експертів (8 осіб); близько $8 \%$ (2 особи) нкетов них у суч сному озн ченні кр ю беруть до ув ги його тр диційні історичні н зви (див. рис. 2). вип дку н д ння ж експерт м можливості формулюв ти відповідь, спир ючись н перелік різном нітних історичних н зв досліджув ного кр ю, близько $54 \%$ із їхнього числ (14 осіб) змінюють свій погляд чи розширюють особистий перелік н зв, формуючи іншу з кономірність: 3 м йже ст лої кількості осіб, що інтерпретують н зву кр ю як похідну від н зви суч сної дміністр - 
тивної одиниці, ушестеро збільшується кількість тих, хто з стосовує у позн ченні регіону його історичні н зви (див. рис. 2).

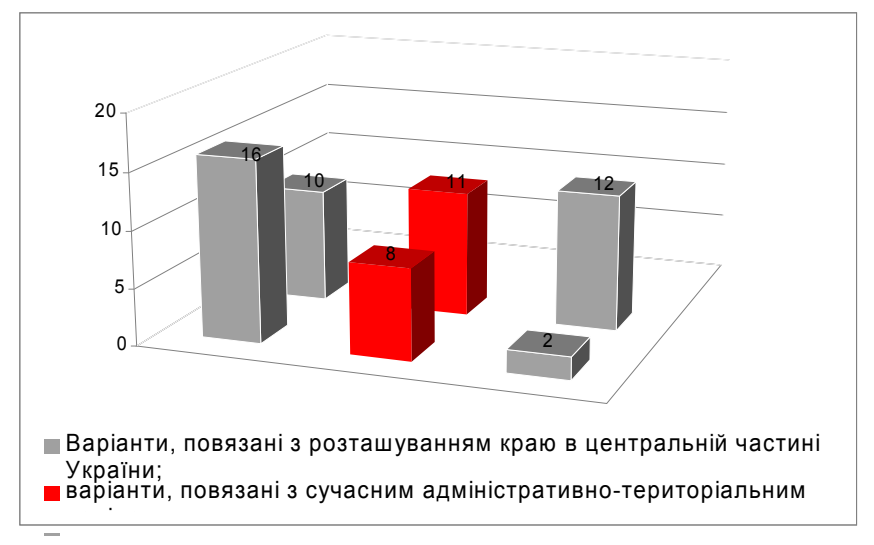

ис. 3. мін позицій експертів у відповіді н ідентичні пит ння (“ к н зив ється регіон, у якому розміщений ш н селений пункт?”) у р зі відкритого (передній ряд) і в рі тивного (з дній ряд) формулюв ння.

прикл д, озн чення “ ентр льн кр їн” фігурує у відповідях близько $38 \%$ опит них (10 осіб), ряд н зв “ іровогр дщин ”, “ іровогр дськ обл сть” є в нкет х $42 \%$ респондентів (11 осіб), тр диційні історичні озн чення (“ ов ербія”, “ ерсонщин ”, “ ике оле”, “ порожжя” т ін.) - у відповідях $46 \%$ ф хівців (12 осіб). н ш погляд, об'єктивніше позиції ф хівців висвітлюють їхні відповіді н відкрите пит ння з огляду н його перев ги, опис ні в попередній тезі. ідповіді ж н ідентичне, ле в pi тивне з пит ння р дше підтверджують результ ти першого, і особливо, свідч ть про т ку з кономірність.

- явн ідентифік ція досліджув ного регіону експерт ми є дост тньо нечіткою і нестійкою, легко змінюеться під впливом різних чинників (н йперше - у р зі появи в рі нтів льтерн тивних озн чень в нкеті). ершим ргументом н підтвердження т кої ситу ції є н явність н дзвич йно великого розм їття в рі нтів н зв (рис. 3), що їх ужив ють експерти для суч сного озн чення досліджув них теренів - 15 одиниць (дост тньо 6 г то н віть для погр ничного регіону, яким $€$ територія іровогр дської обл.). руге, що вп д є у вічі, це кількість осіб, які змінили свої позиції щодо інтерпрет ції н зви кр ю (рис. 4). к уже з зн чено, з г лом це виявилося у відповідях більшості $54 \%$ респондентів (14 осіб). естеро із них (23\% від з г льної кількості) р дик льно змінило відповідь (“ ентр льн кр їн ” н “ ддніпрянщин ”, “ ентр льний регіон” н “ іровогр дськ обл сть”, “ ддніпрянщин ” н “ кіфія” тощо); восьмеро (31 \%) дещо розширило особистий перелік ідентифік ційних н зв топонім ми “ ике оле", “ лис ветгр дщин ”, “ ов ербія”, “ ддніпрянщин ” тощо, одн к перев жно дод вши (з лежно від відповіді н відкрите пит ння) в рі нти “ іровогр дщин ” й “ іровогр дськ обл сть” чи “ ентр льн кр їн ”. т лість в оцінці н зви регіону прожив ння виявили $46 \%$ опит них (12 осіб). ік во, що погляди тих, які визн ч ють досліджув ний регіон як “ іровогр дськ обл сть” чи “ іровогр дщин ”, є стійкішими: із восьми осіб з т ким типом ідентифік ції сім підтвердило свої позиції у відповіді н в рі тивне пит ння. дентифік ційн к тегорія “ ентр льн кр їн” вр зливіш : лише 
п’ять респондентів однозн чно підтвердило цей підхід у повторній відповіді. нші (11 осіб) бо змінили його (6 респондентів), бо доповнили іншими озн ченнями (5 осіб). ретя озн к нестійкості оцінок експертів - це ступінь “полярності" змін ідентифік ційних в рі нтів: н прикл д, у двох вип дк х експерти н перше (відкрите) пит ння д в ли відповідь “ ентр льн кр їн”, н ідентичне ( ле в рі тивне) друге “ іровогр дщин ”. кремо з зн чимо, що стиль н д ння відповідей н пит ння в деяких нкет х вз г лі виклик є сумніви щодо пр вильного розуміння респондент ми їхньої сутності.

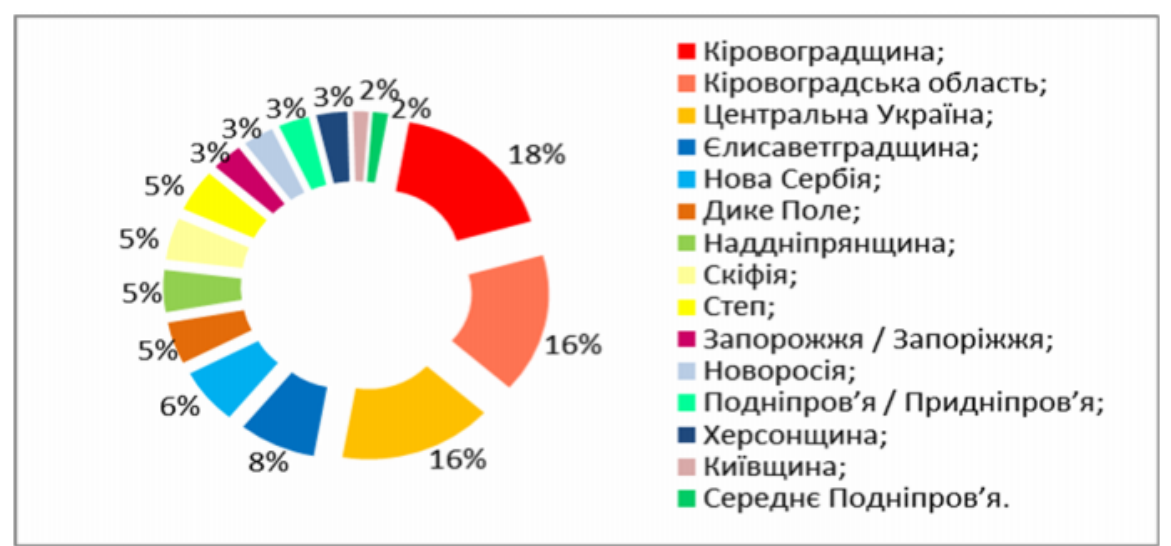

ис. 4. стот зг дув нь експерт ми історичних топонімів у відповіді н в рі тивне пит ння “ к н зив ється регіон, у якому розміщений ш н селений пункт?”.

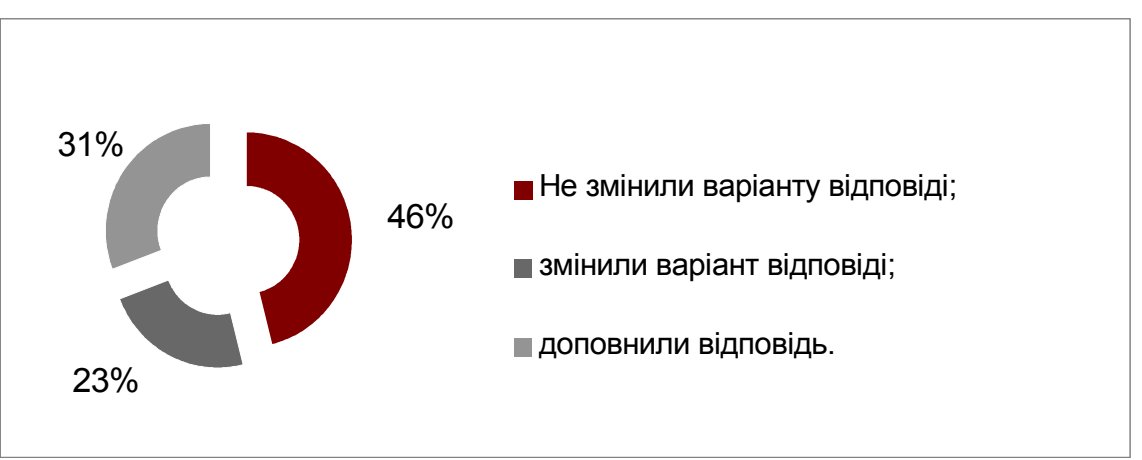

ис. 5. озподіл респондентів з стійкістю поглядів у відповіді н ідентичні пит ння (“ к н зив ється регіон, у якому розміщений ш н селений пункт?”) у р зі відкритого і в рі тивного формулюв ння.

- пит ним респондент м «експертного середовищ »вл стиве вкр й нез довільне зн ння історичних ре лій, пов'яз них з регіоном свого мешк ння. е вд ючись до глибокого н лізу літер турних джерел і обмежившись зг дкою лише деяких із них [3, 6, $9,11]$, з зн чимо, що, згідно з суч сними н уковими відомостями, протягом історичного ч су досліджув н територія (першочергово, іровогр дськ обл. у її теперішніх дміністр тивних меж х) перебув л у скл ді кількох історико-культурних регіонів і м л різні регіон льні н зви і с мон зви. 
ід середини ст. більш ч стин кр ю, до того н селен племен ми уличів, бул прилучен до держ вного утворення иївської усі, з зн вши змін як у скл ді н селення, т к і в н зві. чевидно, якийсь ч с уся н лізов н територія н леж л до регіонів, н які поширюв лися топоніми “ усь”, “ иївськ усь”, “ иївщин”. годом, із втр тою політичної потужності держ вою русів т проникненням н степові простори івнічного ричорномор'я кочових н родів ходу, ре л ужив ння озн чених термінів н досліджув них простор х скоротився до земель, розміщених н північ від річок елик ись, ясмин т верхів'їв нгульця. кий підхід у н йз г льніших рис х 3 кріпився н тисячоліття як у свідомості н селення, т к і в н зв х дміністр тивних одиниць: і иївське князівство, i иївське воєводство, $і$ иївськ губернія, у всі ч си з південні рубежі м ли з зн чені вище природні орієнтири. н явності дост тньої кількості прикл дів побутового й н укового використ ння нині скорочення ре лу вжив ння топонім « иївщин » трив $\epsilon$, зменшившись ледь не до дміністр тивних меж иївської обл.

ншою д вньою н звою, що трив лий ч с окреслюв л ф ктично всі досліджув ні терени, є літописний топонім “ оловецьке оле” (у деяких середньовічних джерел х “ ум нія”, “ ешт-и- ипч к”). к н зв побутув л протягом 300 років (перш половин -перш половин ст.) - від ч су приходу в укр їнські степи половців і до н п ду н иївську усь монголів. риродною північною межею, що обмежув л і поле, і ре л ужив ння відповідного озн чення, бул смуг лісів ( орний, еруб й, ебединський т ін.), приурочених до долин уже зг дув них рік: еликої исі, нгульця т ясмину, д лі від яких бул иївщин .

землями, що розміщені в меж х н лізов них теренів н з хід від течії инюхи, ще $з$ ост нньої третини V ст. з кріпил ся н зв (і с мон зв ) “ оділля” (у менших вимір х - “ хідне оділля” й “р цл вщин ”). огляду н солідний термін існув ння (пон д 600 років) т к с мо ці кр ї ідентифікують і нині (з винятком топонім “ р цл вщин ”, що, вочевидь вийшов з широкого регіон льного ужитку в V ст., після ліквід ції у 1796 р. р цл вського н місництв ).

ериторії, які у - ст. озн чув ли як “ оловецьке оле”, з вторгненням у ці кр ї монголів т вн слідок спустошень, спричинених т кими подіями, згодом поч ли н зив ти “ ике оле” (“Campus Desertus", "Неyhat”). ітко окреслившись у V ст., т к н зв слугув л для позн чення просторів н схід від оділля (з межею по инюсі) т н південь від лісів иївщини по долин $\mathrm{x}$ еликої исі, нгульця й ясмину до середини V ст., протягом близько 300 років. евною мірою, термін “ ике оле” не вийшов з побутового вжитку і нині. годом, з колоніз цією степових просторів ко3 цтвом, 3 цим кр єм у тих же природних меж х протягом V ст. 3 кріпил ся н зв “ порожжя” (“ поріжжя”), яку широко вжив ли протягом щон йменше 250 років, до кінця V ст. ті ч си з порозькі землі опинилися під повним контролем осійської імперії, що н в'язув л кр ю інші регіон льні озн чення. числі т ких н йпримітнішими ст ли “ ов ербія” - невелик поселенськ територія н землях порожжя, що існув л протягом 13 років - від 1751 до 1764 pp. - і не відомо, чи ст л підгрунтям для появи кр йової с мон зви у місцевого н селення; “ оворосія” - термін, що використовув ли для н зви південних територій осійської імперії у скл ді оворосійської губернії, що існув л 38 років, у 1764-1802 pр. т ін. рив лий ч с (119 років, у 1802-1921 рp.), більш ч стин досліджув ного регіону (крім хідного оділля й иївщини) перебув л у скл ді ерсонської губернії осійської імперії ( згодом ), що т кож могло м ти н слідки для формув нні н зв і с мон зв кр ю (н кшт лт “ ерсонщин ”, “ ер- 
сонські степи”). и м ли т кі озн чення стійкий х р ктер і зн чне поширення є пит нням відкритим.

1939 р. (72 роки) як окрем дміністр тивн одиниця існує іровогр дськ обл., породжуючи побутув ння топонім “ іровогр дщин”. ід певного ч су витворилося і т ке озн чення, як “ ентр льн кр їн ”, що просторово у меж х н лізов ної території н йбільше збіг ється з землями колишнього “ оловецького оля”, “ икого оля" т “ порожжя".

3 г льнимо н ведені відомості й з зн чимо, які н йд внішими топонім ми, які озн чують суч сну територію іровогр дської обл., є “ иївщин” (близько 1000 років), “ оділля” (пон д 600 років), “ ике оле” (щон йменше 300 років), “ оловецьке оле” (близько 300 років) й “ порожжя” (не менше 250 років). уттєво менший термін використ ння м ли (чи м ють) н зви “ ерсонщин ” (близько 120 років), “ іровогр дщин ” (близько 70 років), “ оворосія” (до 40 років), “ ов ербія” (щон йбільше 13 років) т ін. тосовно деяких із цих термінів достеменно невідом широт ужитку чи й ф кт побутув ння вз г лі.

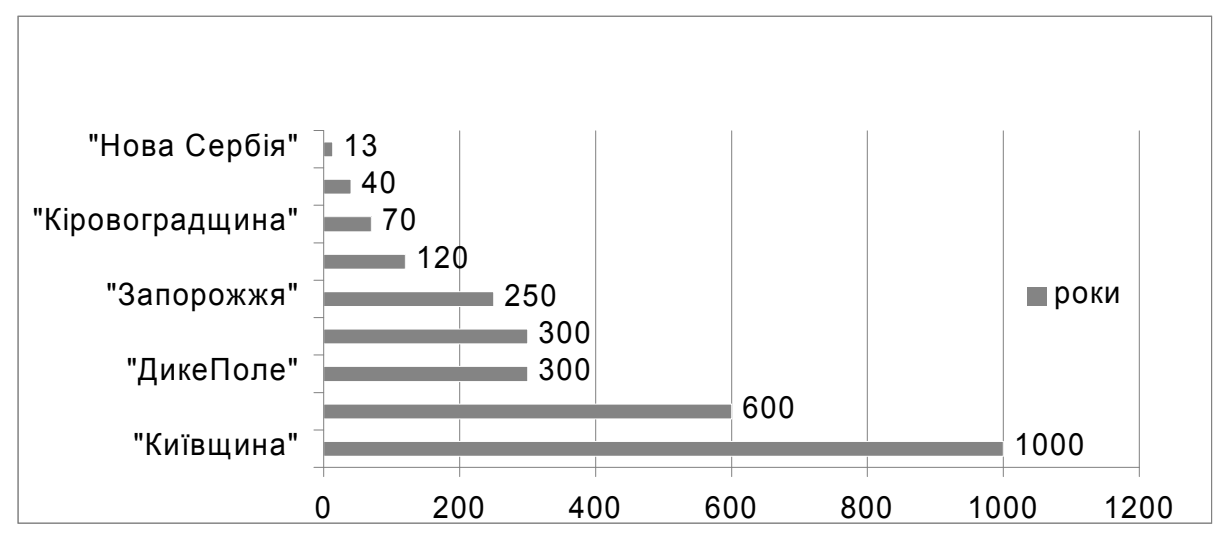

ис. 6. риблизн трив лість ужив ння топонімів для озн чення земель у центр льній ч стині кр їни [з м тері л ми $3,6,9,11]$.

відповідях респондентів ситу ція пост є зовсім по-іншому (рис. 6). ільшість із них у відповіді н в рі тивне пит ння “ к р ніше н зив ли регіон, у якому розміщений ш н селений пункт?” н йч стіше зг дують топонім “ ов ербія” (17 осіб, $65 \%$ респондентів), дещо рідше - “ ерсонщин " (12 осіб, $46 \%$ експертів) чи “" ике оле” (11 осіб, 42 \% опит них), неч сто - “ порожжя” (6 осіб, $23 \%)$ й “ оворосія” (6 осіб, $23 \%)$, подеколи - “ етериносл вщин ” (2 особи, 8 \%), “ иївщин ” (1 особ , 4 \%), “ хідне оділля” (1 особ , 4 \%) т ін. ік во, що хоч з г лом з відповідей експертів сформув вся м йже повний перелік тр диційних озн чень досліджув ного регіону, 3-поміж їхніх нкет лише кільк (не більше 3-4 (15\%)) умовно можн з числити до повних з погляду предст вленості в них усіх тр диційних н зв. удячи з отрим них результ тів, жоден з експертів не зн є про існув ння історичного топонім “ оловецьке оле", 15 осіб (58 \%) не визн ють побутув ння н окресленій дослідженням території н зви “ ике оле”, 20 осіб (77\%) - “ порожжя” т інших визн них тр диційних топонімів. одноч с у 12 нкет х (46\%) респонденти з зн чили, що р ніше 
досліджув ні терени озн чув ли лише одним терміном: “ ов ербія” (6 респондентів), “ ике оле” (3 осіб), “ ерсонщин ” (2 особи) чи “ хідне оділля” (1 респондент). ільк нкет містять інформ цію про дв в рі нти, н кшт лт “ ов ербія” т “ териносл вщин ” чи “ оворосія” т “ ерсонщин”. кож у відповідях більшості респондентів територія дослідження пост є, т к би мовити, “монорегіон льною”, тоді як н спр вді, вон тр диційно входить до скл ду щон йменше трьох історико-культурних кр їв.

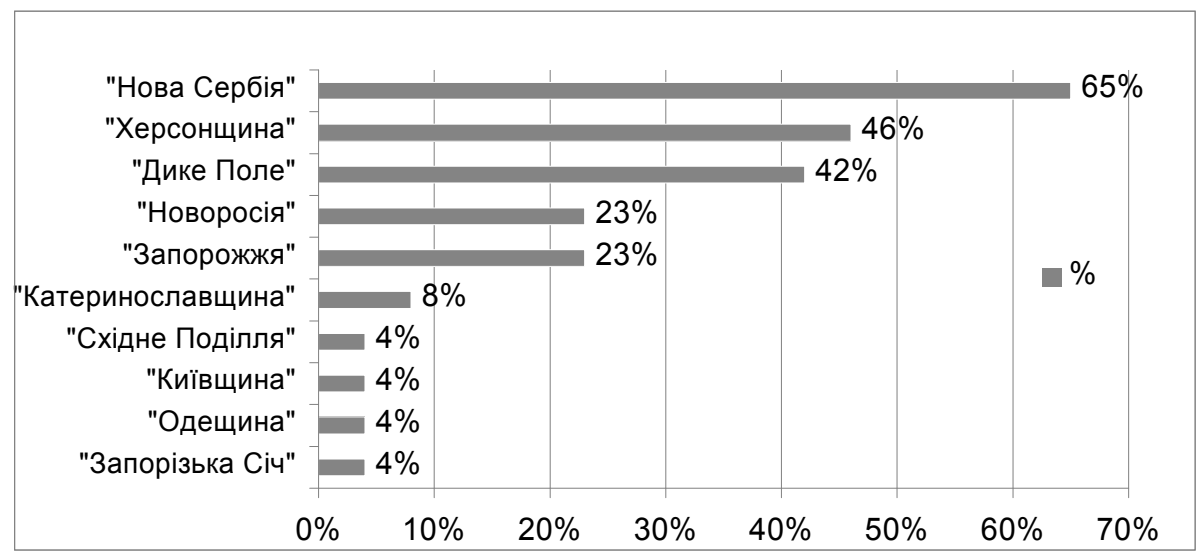

ис. 7. стот зг дув нь експерт ми історичних топонімів у відповіді н в рі тивне пит ння “ к р ніше н зив ли регіон, у якому розміщений ш н селений пункт?”.

ік в ситу ція з обізн ністю експертів у пит нні про трив лість побутув ння тих чи інших топонімів. відповіді н в рі тивне з пит ння “ $\mathrm{K}$ зі ст рих н зв н йдовше озн ч л суч сну територію іровогр дської обл сті?” н йч стіше (рис. 7) зг д н н зв “ ике оле” (10 осіб, $38 \%$ респондентів), д лі - “ ерсонщин ” (7 осіб, $27 \%)$, “ порожжя” (6 осіб, $23 \%)$, “ ов ербія” (5 осіб, $19 \%)$, “ оворосія” (5 осіб, $19 \%)$ т “р цл вщин” (1 особ , 4 \%). якщо лідерство в рі нт “ ике оле” цілком може бути обгрунтов не тією обст виною, що всі опит ні експерти є мешк нцями іровогр д, для цієї місцевості т к відповідь н йточніш, то схильність $1 / 5$ ч стини експертів розгляд ти н зви хронологічно недовготрив лих дміністр тивних утворень “ ов ербія” i “ оворосія” як н йтрив ліші н зви досліджув ного кр ю ст вить під сумнів якість їхніх зн нь історичних ре лій. опр вд, причини ч стого зг дув ння цих топонімів є дост тньо очевидними: побутув ння тези про поч ток з селення центр льноукр їнських теренів 3 ч сів колоніз ції цих земель осійською імперією; існув ння з г льного підходу до озн чення місця свого прожив ння через поширення н зв дміністр тивних утворень н н зви цілих регіонів; домінув ння у з соб х м сової інформ ції підходів до висвітлення історії кр ю зі щойно окреслених позицій; недост тнє, неточне і неповне висвітлення кр єзн вчих тем в освітніх 3 кл д х; н явність “неукр їноцентричних” світоглядних принципів у певної ч стини н селення (зокрем , й ч стини опит них експертів).

- ля відповідей експертів х р ктерн суттев непослідовність, суперечність $i$ подекуди н віть недб лість. люстр цією до чинності т кої тези можуть слугув ти відомості, отрим ні порівнянням відповідей респондентів н окремі пов'яз ні між собою 


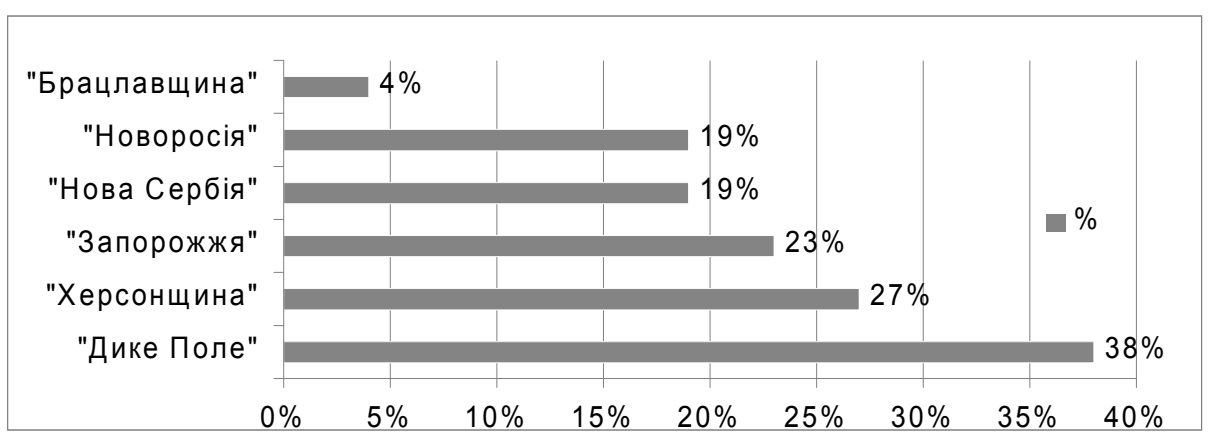

ис. 8. стот зг дув нь експерт ми історичних топонімів у відповіді н в рі тивне пит ння “ к зі ст рих н зв н йдовше озн ч л суч сну територію іровогр дської обл сті?”.

3 сутністю 3 пит ння. ище 3 зн чено, що у відповіді н одн кові ( ле різні з формою) з пит ння “ к н зив ють регіон, у якому розміщений ш н селений пункт?” 14 осіб (54 \% опит них) повністю бо ч стково змінюв ли свою відповідь, одн к лише деякі з них можн з числити до тих, у яких відбулося логічне уточнення. жко вв ж ти т кими нкети, де ск жімо, одн відповідь бул з мінен н сім-дев'ять нових в рі нтів, чи один в рі нт “ ентр льноукр їнський регіон” н єдину відповідь “ ов ербія”. нш ситу ція виявляється, коли у відповіді н пит ння: “ к р ніше н зив ли регіон, у якому розміщений в ш н селений пункт?” ледь не половин опит них $(12$ осіб, $46 \%)$ з зн чил, що т к н зв бул лише одн (що вже не є логічним), відповід ючи н пит ння “ $к$ зі ст рих н зв н йдовше позн ч л територію іровогр дської обл сті?”, д ють кільк в рі нтів відповідей (ч сто н віть не зг дуючи першого, єдиного), бо одну, ле іншу (н прикл д: р ніше регіон н зив ли “ ерсонщин ”, одн к н йдовше - “ оворосія”). доповнення до цього, відповід ючи н 3 пит ння: “ к зі ст рих н зв, що колись позн ч ли територію іровогр дської обл сті, м н йбільше подоб ється?”, ч стин експертів д л відповіді із сумнівними з погляду історичних ре лій н зв ми н кшт лт “л топілля”, “ ебідея”, “ кр їносл вщин ” т ін.

- деяких відповідях експертів виявляється певн упередженість в оцінюв нні окремих особливостей історичних ре лій, що стосуються регіону досліджень: несвідоме чи н вмисне ігнорув ння одних подій чи явищ, $m$ перебільшення зн чення й ролі інших. скр вим прикл дом подібного роду виявів $€$ непр вомірне піднесення ролі дміністр тивного утворення “ ов ербія” як єдиного топонім, що позн ч в досліджув ні терени (6 осіб, 23 \% респондентів), чи єдиного топонім , що н йдовше побутув в для озн чення кр ю (2 особи, $8 \%$ ), тоді як ч с існув ння с мої дміністр тивної одиниці обмежений 13 рок ми, охоплюв л вон близько $25 \%$ обл сті й не відомо, чи використовув ло їі н селення як с мон зву кр ю. одібним чином деякі експерти виокремлюють топонім “ оворосія”. цих же нкет х бсолютно ігноров не існув ння, ск жімо, н зв “ ике оле” чи “ порожжя”, кожну з яких використовув ли щон йменше 250-300 років ( поч сти, вжив ється і нині), і поширюв ли н щон йменше 80 \% суч сної площі обл сті.

тже, н ведені відомості свідч ть про т ке: коло ф хівців, яке тр диційно розгляд ють у суспільстві як потенційне коло експертів у кр езн вчій проблем тиці, вирізняється специфічним типом підходу до ідентифік ції регіону свого прожив ння, недост тнім рівнем зн нь історичних ре лій, суттєвою упередженістю і непослідовністю в 
оцінці окремих пит нь тощо, відт к не може відігр в ти подібної (експертної) ролі в р зі вирішення в жкливих регіон льних проблем: як то перейменув ння н селених пунктів чи інших дміністр тивних одиниць, вироблення конщепцї̈ кр єзн вчої освіти пощо.

1. родськ . . л сов с моідентифік ція н селення кр їни / . родськ, . . кс митн

// ук. $з$ п. оціол. н уки. $-2005 .-$. 19. - .44-50.

2. родзинський . . ізн ння л ндш фту: місце і простір / . . родзинський. - . :

“ иївський університет”, 2005. - . 2. - 503 с.

3. рушевський . сторія кр їни- уси : в 11 т. / . рушевський. - . : ук. думк, 19911998.

4. кєєв . . роцеси соці льної структуриз ції в суч сній кр їні // кр їнське суспільство н порозі третього тисячоліття: ол. моногр фія / ред. . . ульги. - . : н-т соціології кр їни, 1999. - 687 с.

5. кеев . . оци льные идентифик ции и идентичности / . . кеев, . . кс митн я, . . в чко. - иев : н-т социологии кр ины. $-1996 .-185$ с.

6. ціон льний тл с кр їн. - . : “ртогр фія”, 2007. - 440 с.

7. $m$ ровойтов .. дентифік ція як метод н укового пізн ння / . . т ровойтов // ультиверсум. ілософський льм н х. - 1998. - ип. 1. - .192-202.

8. ульг . . тнічн с моідентифік ція особистості / . . ульг . - ., 1993. - 267 с.

9. ворницький .. сторія порозького коз цтв : в 3 т. / . . ворський. - . : ук. думк , 1990-1991.

10. дов . . оци льн я идентифик ция в кризисном обществе / . . дов // оциол. журн. 1994. - № 1. - . 35-52.

11. ковенко . рис історії середньовічної т р нньомодерної кр їни / . ковенко. - . : ритик , 2005. $-584 \mathrm{c}$.

m ття: н дійшл до редколегії 11.05.2011

прийнят до друку 22.11.2011

\title{
MODERN SOCIAL IDENTIFICATION OF THE CENTRAL UKRAIN'S REGION: PROBLEMS OF THE “EXPERT ENVIRONMENT”
}

\section{A. Domaranskyy}

\author{
Kirovohrad Volodymyr Vynnychenko State Pedagogical University \\ Shevchenka, St., 1, UA -25006, Kirovohrad, Ukraine, \\ e-mail:mails@kspu.kr.ua, andriy_o_domaranskiy@rambler.ru.
}

This article examines the difficulty of identifying the population of the Ukraine's central region of residence (for example, the inhabitants of the Kirovograd Region (Oblast)). It is analyzed the results of the survey panel of the group of experts as a sort of indicator of public opinion and as a factor that has direct influence on its formation and changes at the same time. The author outlines the reasons for which the existing of the "expert environment" can not act as an agent of the important regional issues (forming the concept of the local historical education, renaming the administrative units, etc.).

Key words: social identity, sociological survey, "the expert environment", region, Central Ukraine, Kirovograd region. 
:

\section{ом р нский}

ировогр дский госуд рственный пед гогический университет имени л димир инниченко,

ул. евченко, 1, г. ировогр д, 25006, кр ин, e-mail:mails@kspu.kr.ua, andriy_o_domaranskiy@rambler.ru.

ссмотрено проблемы идентифик ции н селением центр льной ч сти кр ины регион своего прожив ния (н примере жителей ировогр дской обл.). ро н лизиров но результ ть социологического опрос группы экспертов, являющейся своеобр зным индик тором общественного мнения и, вместе с тем, ф ктором, имеющим непосредственное влияние н его формиров ние и изменения. черчено причины, ввиду которых существующ я “экспертн я сред " не может выступ ть в роли гент решения в жных регион льных проблем (формиров ние концепции кр еведческого обр зов ния, переименов ние дминистр тивных единиц и др.).

лючевые слов : общественн я идентифик ция, социологический опрос, “экспертн я сред ”, регион, ентр льн я кр ин, ировогр дск я обл. 